\title{
The Imperial Shrines of Ise: An Ancient Star Cult?
}

\section{Mark Teeuwen}

\begin{abstract}
Japan's ancient imperial cult has consistently been understood to revolve around the figure of the sun-goddess and imperial ancestor Amaterasu. The symbolism of Amaterasu's shrine in Ise has been interpreted on the basis of this same premise. There is, however, one dissenting voice: the work of Yoshino Hiroko, who argues that behind the solar façade, imperial worship of Ise reflected an ancient star cult of Chinese origin. This paper finds arguments both for and against this daring hypothesis.
\end{abstract}

\section{Introduction}

Wherever they are in the world, few ancient monuments escape the fate of being interpreted as sites of secret star cults. The pyramids in Egypt, the temples of the Aztecs, and the stones of Stonehenge spring to mind as typical examples. The evidence that is adduced to support such interpretations usually refers to the orientations of buildings and rituals, and relates these to the angles of the sun, the moon and certain stars or constellations at certain times of the year, or even at specific points in a cycle of years. Star cult theorists see the monuments that they interpret as models of the cosmos, and they argue that these monuments served to confer cosmic meaning on the activities of the people or the elites who built and used them. The sheer grandness of their theories makes them fascinating and extremely exciting; yet, at the same time, the evidence often remains circumstantial and difficult to judge. We would love to be convinced, but at the same time we are exasperated at having to make a leap of faith. In the end, the data that are available often remain elusive and open to multiple interpretations.

Japan, too, has its star cult theorist. Her name is Yoshino Hiroko, and her speculations are as enticing as any. I have been both attracted to and frustrated by her work for a long time. As long ago as 1986, Yoshino

Mark Teeuwen, 'The Imperial Shrines of Ise: An Ancient Star Cult?', Culture and Cosmos, Vol. 10 no 1 and 2, Spring/Summer and Autumn/Winter 2006, pp. 79-98.

www.CultureAndCosmos.com 
80 The imperial shrines of Ise: An ancient star cult?

Hiroko published a book entitled Daijosai 大嘗祭 ('The Ritual of Great Tasting'). Recently, it was republished almost unchanged in a pocket version with the more accessible title Tennō no matsuri 天皇の祭り, 'The Rituals of the Emperors.' ${ }^{1}$ This book is a bold attempt to explain the most important imperial rituals of the classical court as a star cult, based on Chinese astrology. Yoshino asks questions that more traditional historians have not even considered. She gives us answers that force us to reconsider our received understanding of the central symbols and sites of Japanese emperorship with an open mind. But how convincing is her theory of ancient imperial star worship?

\section{Tenmu: the first Japanese emperor?}

Yoshino begins her story with emperor Tenmu (r. 672-686). Tenmu came to power in the so-called Jinshin war of 672, a campaign in which he wrested the throne from his cousin, prince Ōtomo. Yoshino's premise is that after his victory, Tenmu radically redesigned both the daijosai, the first harvest ritual performed by new emperors, and the rituals of the Ise shrines, the sanctuary where the imperial house worships its ancestral deity Amaterasu as well as other (minor) imperial deities. Together, the daijosai and the cult of Ise have served as the axis of imperial ritual up to this day. As the grand designer of these two ritual spaces, Tenmu emerges in Yoshino's book as the very creator of Japanese emperorship.

Yoshino is not alone in giving Tenmu such a central role. Many historians have characterised Tenmu as the father of the Japanese imperial state. There is a growing consensus that Japan acquired its modern name, Nihonkoku 日本国 or 'Land of the Rising Sun,' during Tenmu's reign, and as we shall see below, it also appears more and more likely that Tenmu was the first Yamato king to adopt the title that we usually translate as 'emperor' (tennō 天皇, literally 'heavenly sovereign') to mark his position as the ruler of this newly-named realm. In this sense, Tenmu was quite likely the first 'emperor' of 'Japan.' It was definitely Tenmu who gave orders for the compilation of the Kojiki 古事記 (712), Japan's first imperial history, in which the grand plot of imperial myth was to be established once and for all. Tenmu also set up the first court institution dedicated exclusively to the worship of the kami (at this time called kamitsukasa 神司, a predecessor of the later jingikan 神祇官).

1 Yoshino Hiroko 吉野裕子, Daijōsai 大嘗祭, Tokyo: Kōbundō 1987 and Tennō no matsuri 天皇の祭り, Tokyo: Kōdansha, 2000.

Culture and Cosmos 
There is some evidence to suggest that the daijosai was established as a ritual clearly distinguishable from the annual niiname 新嘗 harvest rituals during his reign, ${ }^{2}$ and Yoshino is not alone in interpreting this as a clear sign that Tenmu played a prominent role in the design of the daijosai.

Also, there is little doubt that Tenmu had a special interest in Ise. The region of Ise had been important in the Jinshin campaign, and scattered facts from another imperial history, the Nihon shoki 日本書紀 (720), indicate that Tenmu felt a special connection to its shrines. While his predecessors (from Jomei, r. 629-641, to Tenji, r. 668-671) had shown no interest in Ise at all, Tenmu sent one of his daughters to Ise to lead the worship of its deities. With this, he introduced (or revived?) an elaborate system of sending imperial 'dedicated princesses' to the Ise shrines, ${ }^{3}$ a system that was to symbolise the centrality of the Ise cult within imperial ritual. Moreover, Tenmu separated the Outer Shrine of Ise from the Inner Shrine by assigning each of them to separate priestly clans. According to some, he also introduced the shrine's grandest ritual of all: the ritual rebuilding of the shrines every twentieth year (shikinen seng $\bar{u}$ 式年遷宮). All in all, Tenmu clearly played a central role in the first formulation, or at least in the reformulation of Japan's imperial symbolism, and it is quite natural to assume that the daijosai ceremony and the rituals of the Ise shrines would express this symbolism most poignantly.

\footnotetext{
2 For a different view see Okada Seishi 岡田精司, 'Daiō shūnin girei no genkei to sono tenkai 大王就任儀礼の原型とその展開' (in Iwai Tadakuma 岩井忠熊 and Okada Seishi, eds, Tennō daigawari gishiki no rekishiteki tenkai 天皇代替り儀式の歴史的展開，Tokyo：Kashiwa Shobō，1989，pp. 7-50). Okada argues that the daijōsai was institutionalised by empress Jitō (Tenmu's sister and successor), who issued the Kiyomihara law code (681-89). He does, however, agree that the practice that differentiates the once-in-a-reign daijosai from the annual niiname was introduced by Tenmu (see pp. 38-39). Tenmu initiated the appointment of two provinces called yuki and suki (terms that we will encounter again below), which were to prepare special offerings for the harvest festival. The question is whether Tenmu with this innovation instituted the daijosai, or whether he intended this only as an extension of the annual niiname. Okada offers convincing arguments for the latter view.
}

3 It is possible that this practice was first introduced during Suiko's reign in the first decade of the 7th century, and since lapsed into oblivion. Either way, Tenmu's reintroduction was an important innovation. 
82 The imperial shrines of Ise: An ancient star cult?

\section{The Pole Star and the Northern and Southern Dippers}

Central to Yoshino Hiroko's work is her claim that the imperial rituals of the daijosai and Ise focus on the Pole Star and two constellations, the 'Northern Dipper' (hokuto 北斗, better known to us as the Great Bear or Ursa Major) and the 'Southern Dipper' (nanto 南斗, a traditional Chinese constellation consisting of six stars that form part of Sagittarius). This is surprising, because we are used to hearing that the focus of imperial kami ritual was on the sun-goddess, Amaterasu, as the ancestor of the emperors' solar dynasty. In short, Yoshino's thesis is that Tenmu identified both himself and Amaterasu with the Pole Star, and that he designed his imperial cult around this central idea.

This, too, is not at all as unreasonable an idea as it may sound. As many historians have pointed out, the term tennō (Chinese tianhuang) itself was adopted in Japan from Chinese sources, where it referred to the Pole Star. As possible sources for the term in Japan, Shimode Sekiyo (who has written on Taoism and Yin-Yang thought and ritual in ancient Japan) points to Sima Qian's Records of the Historian (Shiji 史記) and to texts that belong to a genre called weishu 緯書. The term weishu may be translated as 'woof books,' as in 'warp and woof'. ${ }^{4}$ These books interpreted the classical texts, called jing 経 or 'warp books', in a manner that may be described as kabbalistic, with the aim of reading the future or performing divination. One such text, the 'Spring and Autumn woof book,' simply states: 'The heavenly sovereign and great emperor (tianhuang dati 天皇大帝) is the Pole Star.' The same identification can also be found on early Chinese star charts, where the Pole Star is marked with the word tianhuang. It even makes an appearance in Confucius' Analects (2.1). Confucius compares the ruler who exercises government by means of his virtue to 'the Pole Star, which keeps its place while all the stars do homage to it.'

There is some discussion as to the date when this term tianhuang or tennō was first adopted in Japan. According to the pre-war historian Tsuda Sōkichi, who published an essay on this question in 1920, this happened during the reign of Suiko (r. 593-628). In the 1960s, Ishimoda Shō suggested that the title was introduced from Korea as early as the mid-sixth century, in the time of Kinmei (r. 539-571?). More recently,

4 Nihon kodai no dōkyō, onmyōdō to jingi 日本古代の道教・陰陽道と神祇, Tokyo: Yoshikawa Kōbunkan, 1967, pp. 71-92.

Culture and Cosmos 
however, doubt has been cast on Tsuda's and Ishimoda's evidence, and most historians now prefer a date towards the end of the seventh century, during the reign of Tenmu (r. 673-686). This hypothesis was strengthened in 1998, when a wooden document (mokkan 木簡) containing the word tennō was excavated in Asuka, the area that formed the pre-Nara core of the Yamato court. This document was dated to 677, which corresponds to the reign of Tenmu. To date, it represents the earliest reliable attestation of the term in Japan.

In this light, Yoshino's theory that Tenmu used star lore to reform imperial ritual could make sense. If the title of tennō means 'Pole Star Monarch' (to borrow the translation of Joan Piggott ${ }^{5}$ ), and if it was Tenmu's intention to give ritual expression to his position as tennō by redesigning Ise and the daijōsai, then it would indeed be strange not to find any references to the Pole Star and related star symbolism in those rituals. The palace Tenmu constructed at Kiyomihara was awash with Chinese cosmological imagery. At grand New Year's receptions, the emperor would sit on an octagonal platform in the 'Hall of the Great Ridgepole' (Daigokuden 大極殿; 'Great Ridgepole' is another designation for the Pole Star), surrounded by banners emblazoned with cosmological symbols, and wearing a silk gown that had a large image of the Northern Dipper sitting right between his shoulders.

Like Shimode, Yoshino refers to Sima Qian and weishu 'woofbooks' as the sources that informed the star cult of Tenmu's court. Here, the Pole Star is described as the stable centre that all other stars revolve around. Foremost among the stars of heaven were the Northern and Southern Dipper mentioned above. Yoshino quotes passages from Sima Qian that describe the Northern Dipper as the vehicle of the stationary Pole Star, the mobile medium through which the Pole Star spreads its might throughout the universe. The Southern Dipper, on the other hand, was known in classical China as the 'ancestral shrine of heaven,' and was believed to be responsible for the longevity of the emperor. Yoshino mentions the Han capital of Chang'an as a perfect illustration of the use of this stellar imagery to represent the emperor and his court. Chang'an was known as the 'City of Dippers' (toucheng 斗城), because its northern and southern outskirts were said to resemble the shapes of the Northern

5 Joan Piggott, The Emergence of Japanese Kingship, Stanford: Stanford University Press 1997. Strangely, Piggott applies this term to the reign of Suiko, while at the same time supporting the view that it was introduced to Japan in Tenmu's time. 
84 The imperial shrines of Ise: An ancient star cult?

and the Southern Dipper. ${ }^{6}$ The 'emperor as Pole Star' at the centre, surrounded by the two dippers representing his vehicle and his ancestral shrine - this image, Yoshino argues, was Tenmu's main source of inspiration when he gave both the Ise shrines and the daijosai their classical forms.

\section{The stars in Ise ritual}

From here Yoshino leaps into uncharted territory. She argues that the offering of foodstuffs to the Pole Star was the overarching idea on which Tenmu's ritual system was based. The two dippers, she contends, served as two 'ladles' (tou 斗), containers in which offerings were served to the Pole Star itself. At Ise, she suggests, the Inner Shrine must have represented the Pole Star, while the Outer Shrine had the function of the Northern Dipper. She points at the term Taiitsu 太-, 'the Great Unity,' used in various Inner Shrine rituals, as a traditional Chinese term for both the Pole Star and the emperor. She also refers to the patterns on two cloth covers that are among the treasures offered to the two Ise shrines even today. First mention of these covers is made in the Engishiki (927), leaving no doubt that they have been included among the 'attire' (shōzoku 装束) that was offered to these shrines since classical times. ${ }^{7}$ The cover that is offered to the Inner Shrine depicts a Chinese-looking hall, appearing to represent a Chinese-style ancestral shrine (Fig. 1), while the Outer Shrine was presented with a cover that carried a pattern of two-wheeled carriages (Figs. 2a \& 2b). Is the Chinese hall meant to represent the shrine of the Pole Star, and the carriage its vehicle, the Northern Dipper?

Starting from this hypothesis, Yoshino proceeds to analyze the

6 Yoshino Hiroko, Tennō no matsuri, p. 95.

7 Shintō taikei 神道大系, vol. Engishiki jō 延喜式上. The cover depicting Chinese-looking halls figures among the attire due to the Inner Shrine as yakata no nishiki no ofusuma 屋形錦御被 ('a brocade cover with a pattern of buildings,' p. 130), while the corresponding list for the Outer Shrine mentions 'two brocade covers with a pattern of carriages' (sashiguruma no nishiki no ofusuma 刺車錦御被, p. 133). Engishiki is the first text to give detailed lists of Ise offerings; it is difficult, therefore, to ascertain how old these patterns are. Paucity of sources also means that we do not know whether these two covers were as central in discourses on the two shrines in classical times as they obviously were in the medieval period. 
layout and the rituals of the Ise shrines in a very untraditional way. I will cite only a few examples of her daring suggestions, partly because it would take too much space to go through them all, and partly because I do not find them very convincing.

The main annual ritual of Ise is the harvest festival of kanname-sai 神嘗祭. During this ceremony, rice and seafood are offered in front of the central pillar (shin no mihashira 心の御柱) at the main hall of the Ise Inner Shrine, after having been stored for a short period of time in a rice storehouse located close to that hall. If we are to believe Yoshino's analysis, the designers of this ritual identified the storehouse as the shrine of the Southern Dipper. The reason why the rice had to be stored here is that it should be deposited in the ladle of the Southern Dipper before it could be offered to the Pole Star in the main shrine by means of that stellar container. The seafood that was offered at kanname-sai was prepared at the Inner Shrine by the deity of the Outer Shrine, Toyuke. As Amaterasu's mike-tsu-kami 御食津神 or 'deity of divine food,' Toyuke was invited to the Inner Shrine for the duration of the ritual and installed there at a special deity seat, known as 'the seat of Toyuke.' Yoshino argues that seafood was associated with the north, and therefore with the Northern Dipper, which explains both its importance in the proceedings, and the presence of the deity of the Outer Shrine at the Inner Shrine during this ritual alone. Further, she points out that these offerings are traditionally called yuki no omike 由貴大御饌. Yoshino speculates that the term $y u k i$, whose meaning and origin are obscure, may originally have meant 'offering ( $y u$ 輸) in the ladle ( $k i$ 璣) [of the Northern Dipper]. ${ }^{8}$ She is even so bold as to connect this word to the name of the deity of the Outer Shrine, Toyuke 止由気, ignoring the traditional (and linguistically obvious) explanation of this name as 'deity of abundant (toyo 豊) food (uke 食).'

Yoshino also dedicates a chapter to the similarities between the (proposed) star cult of Ise and the daijōsai. ${ }^{9}$ One of her central arguments

8 For an overview of the most current theories on the meaning and origin of these terms, see Nishimiya Kazutami 西宮一民, 'Senso Daijōsai-shiki jūyō goi kōshō 踐祚大嘗祭式重要語彙考証,' in Iwai Tadakuma and Okada Seishi, eds, Tennō daigawari gishiki no rekishiteki tenkai, Tokyo: Kashiwa Shobō, 1989, pp. 51-76. Of course, Yoshino's hypothesis is not among them. 
86 The imperial shrines of Ise: An ancient star cult?

pertains to the special offerings presented at this ritual from two provinces. These offerings are known as yuki 悠紀 no omike (as in Ise, except for the different characters) and suki 主基 no ōmike; Yoshino proposes that both are alternative readings for the same characters that she also suggested as an explanation of the yuki ni omike at Ise. Her conclusion is that yuki no omike and suki no omike were offerings presented to the Pole Star in the ladles of the Northern and the Southern Dipper, respectively. She draws lines between the capital, where the daijossai was performed, and the provinces that were ordered to present the yuki and suki offerings to the palace, and she finds that this angle (67 degrees) coincides with the angle between the two Dippers in the sky at the time of the ritual (Fig. 3). She discovers the same angle also in the layout of the Ise Inner Shrine (Fig. 4) and the Daijoggu 大嘗宮, the temporary shrine set up for the daijōsai (Fig. 5).

\section{Where is the evidence?}

Yoshino's claim, then, is that the court of emperor Tenmu used sophisticated calendrical and astronomical calculations in designing the imperial rituals of daijosai and Ise, and that he encoded in them a secret reference to the Pole Star and its two dippers as the bearing images of imperial power. It is a fact that Tenmu built Japan's first observatory for studying the night sky; in Nihon shoki, he is even introduced as an emperor who was 'skilled in astronomy.' Murayama Shūichi, who pioneered the study of Onmyōdo (Yin-Yang thought and ritual) in the 1980 s, refers at length to Yoshino's work in his Nihon onmyōdō-shi sōsetsu 日本陰陽道史総説 (1991) - quite approvingly, it would seem: '[Yoshino's] hypotheses need to be supported by historical sources, but she leaves no doubt that on the political scene, Onmyōdo had suddenly and rapidly increased in importance [during Tenmu's reign].' Yet, for a number of reasons I find it hard to believe that Tenmu would have gone to such lengths as Yoshino assumes.

Needless to say, Yoshino can quote no scriptural evidence for her code-cracking theories. On the silence of the sources she writes: 'The identification of Amaterasu as the Pole Star was accomplished in secrecy; it must have been guarded as the most secret of secrets. And because in Japan, secrets related to ritual have always been passed on as oral

9 For a detailed description and analysis of this ritual, see Robert S. Ellwood, The Feast of Kingship: Accession Ceremonies in Ancient Japan, Tokyo: Sophia University, 1973.

Culture and Cosmos 
traditions, no priests have left any records of this Pole Star cult' (p. 67). I would like to argue, however, that this view ignores the simple fact that secrets exist to be revealed. It is not just that unrevealed secrets are inaccessible to us, as historians of a later age; even in their own time, secrets that are never revealed by all practical means do not exist. A secret needs both a regime of concealment and a regime of controlled disclosure; otherwise it has no function and no relevance. It is hard to believe that a Pole Star cult would have informed both the daijosai and the rituals of Ise without leaving any traces to that effect in any historical records; it is even harder to argue that such a perfectly kept secret would have been relevant in its own time. And if Tenmu's secret stellar code existed without ever making itself relevant, why should we bother about it?

\section{Problems raised and good questions asked}

Yet, Yoshino's theory explains some facts about Ise that other, more traditional scholars have not even touched upon. Ise, as the prime sanctuary of indigenous Japanese Shinto, has almost exclusively been discussed in terms of a native kami 神 cult, and has served as the hallmark of Japaneseness in an imperial system that was otherwise thoroughly Chinese. But why would Ise have been so different? Was not Ise the shrine complex that was most exposed to Chinese ideas of emperorship of all shrines in the land? Is not Yoshino right that we must expect to find Chinese imperial imagery at its core?

Especially, I am intrigued by Yoshino's explanation of the two covers, and her explanation of them as symbols of the stationary Pole Star and its mobile medium, the Northern Dipper. There is, in fact, some evidence that the patterns on these covers were understood to refer to an unmoving essence and its vehicle; the problem is that that evidence dates from the medieval period. In Hōki hongi 宝基本記, for example, a text that is usually dated to the late twelfth or early thirteenth century, we read that the Chinese-looking building depicted on the cover of the Inner Shrine represents 'the eternal, original residence of the imperial deva (kôten 皇天),' while the cart woven into the cover of the Outer Shrine is 'the vehicle in which [the imperial deva] rides in four directions everywhere under Heaven, in order to save the countless beings' ${ }^{10}$ Here the relationship between the two shrines, as depicted on the covers, is explained in Buddhist terms that form a rough parallel to the astrological

10 Yoshino Hiroko, Tennō no matsuri, p. 71. 
88 The imperial shrines of Ise: An ancient star cult?

meanings that Yoshino reads into them. I would like to point out that kōten 皇天, 'imperial deva,' is a Buddhist-inspired variation on tennō 天皇: the characters are simply turned around, causing the Pole Star monarch to become a Buddhist ten 天 or deva. Has a similar procedure of Buddhist rephrasing been used to redefine the shrine and the vehicle on the covers? Can we assume that the Buddhist interpretation in Hōki hongi draws on an older idea, just like the Buddhist kōten draws on an older tenno $\bar{o}$. Or were the images in themselves powerful enough to inspire the interpretation that we find in Hōki hongi?

However we choose to think about this question, it remains a fact that the covers are older than their Buddhist exegesis in medieval sources, and that as far as I am aware, Yoshino is the only one to give a possible explanation of their original meaning.

\section{Ise reformed in the seventh century}

Taking a broader angle on the problem - why should we assume that the Ise shrines remained largely unchanged in Tenmu's time? Evidence of very dramatic changes during his reign is overwhelming. Already in the 1960s, a more sober historian of early imperial ritual, Okada Seishi, wrote a brilliant article on the early history of the Ise shrines that has remained largely unchallenged. ${ }^{11}$ He points out that a large grave-mound with a total length of 57 metres occupies the summit of a hill called Takakurayama 高倉山, right at the centre of the Outer Shrine precincts. This grave-mound is dated to the early seventh century, and must have served as an impressive monument to the local power of the Watarai 度会 clan, whom Tenmu reduced to hereditary priests of what was at this time renamed the 'Outer Shrine.' The Watarai traced their ancestry to a deity called Ame no Hiwake 天日別, a name in which $h i$ 日, 'the sun' is the meaning-bearing element. Both Takakurayama itself and the gravemound on its summit are oriented to the east, the direction of the rising sun - indicating that the Outer Shrine was the site of an early sun cult that was at the core of the clan tradition of the Watarai. However, the main shrines of the Inner and the Outer Shrines as we know them today are oriented straight north, just like the imperial capital and the imperial palace.

11 'Ise Jingū no kigen 伊勢神宮の起源, part II ch. 4 in Okada Seishi 岡田精司, Kodai ōken no saishi to shinwa 古代王権の祭祀と神話, Tokyo: Hanawa Shobō, 1970.

Culture and Cosmos 
Okada recognises that Tenmu granted control over the 'Inner Shrine' to the Arakida 荒木田 clan, who were local rivals of the Watarai; yet, he assumes that there were already two shrines at this time, and he does not discuss possible changes in the arrangement of the shrine buildings in any detail. He does not consider the possibility that the building of this Inner Shrine was an innovation initiated by Tenmu. He suggests that Ise was chosen as the main site of the imperial sun cult because of its location straight east of the imperial capital Yamato; however, he does not discuss the possible reasons for orienting the shrine complexes of both the Inner and the Outer Shrine to the north. Is there something to Yoshino's suggestion that the shrines are oriented to the north because they were in some way related to the Pole Star, as the bearing symbol of imperial power?

\section{Cult monopolisation}

Okada further argues that Amaterasu, as sun-goddess, imperial ancestor and ruler of the Plain of High Heaven, was a product of Tenmu's court. ${ }^{12}$ He proposes that after his victory in the Jinshin war of 672, Tenmu set out to monopolise sun worship, in order to raise the status of the emperor to that of the sun-deity's divine representative on earth. This strategy was given its ultimate expression in the prohibition of offerings to the Ise sungoddess by others than the emperor, which Okada also traces to Tenmu's time. It is interesting to compare this notion of cult monopolization with repeated attempts to prohibit worship of the Pole Star that were issued from 796 onwards, a century or so after Tenmu. These orders banned worship of the Pole Star for the stated reason that it involved 'mingling of men and women.' Especially, the inhabitants of the capital, the Home Provinces, and the provinces of Ōmi and Ise were on more than one occasion explicitly ordered not to worship the Pole Star when imperial Dedicated Princesses made their way to Ise to begin their ritual service at the shrines. ${ }^{13}$ This prohibition was finally laid down in the Engi shiki 延喜式 (927), which states that 'when the Consecrated Princess is about to enter the Shrine of the Great Deity, from the first till the thirtieth day

12 Ibid., ‘Kodai ōken to taiyōshin 古代王権と太陽神,’ part II ch. 5.

13 This prohibition was laid down first in 799, and is recorded in Nihon kōki, entry for Enryaku 18 (799)/9. See Satō Torao 佐藤虎男, 'Hokushin no sūkei to Watarai-shi no Okazaki-gū 北辰の崇敬と度会氏の岡崎宮, Shintō kenky ū 神道研究 4 (2/3), 1943, p. 194.

Culture and Cosmos 
90 The imperial shrines of Ise: An ancient star cult?

of the ninth month, it is forbidden to light sacred lanterns to the Pole Star in the capital, the Home Provinces and in the provinces of Ise and Ōmi, or to conduct mourning and funerals. ${ }^{14}$ These decrees show that by the late eighth century, rituals in worship of the Pole Star enjoyed some popularity, and also that they were regarded as vulgar and ritually polluting and were therefore subject to a taboo, especially in connection with Ise.

Is this a distant echo of an earlier notion that worship of the Pole Star is also an imperial prerogative, just like worship of Amaterasu? Is it a coincidence that private worship of both the sun-deity and the Pole Star is prohibited in connection with Ise rituals? Or were the rules against Pole Star worship just another example of the growing concern of the court with ritual purity, a concern that is so much in evidence in late eighth century? Or again, are they related to the ban on private use of astronomical tools and texts, a ban that was in force already in the early eighth century? ${ }^{15}$

\section{Pole Star cults at Ise}

However that may be, we can actually find some confirmation of the popularity of Pole Star worship in the Heian period (794-1192) even in Ise itself. At some point in time, worship of the Pole Star became a traditional clan rite of the priests of the Outer Shrine, the Watarai. An image of the Pole Star in his Buddhist guise as Myōken 妙見 was installed in the Okazaki 岡崎 shrine, located in the precincts of the Jōmyōji 常明寺, the clan temple of the so-called 'second branch' of the Watarai, on a hill midway between the Outer and Inner Shrines. An account of the origins of this shrine can be found in Kōkozo to hishō 高庫蔵等秘抄 ('Secret record of Takakurayama and other matters'), a collection of various secret Watarai traditions that was probably compiled in the late thirteenth century but that very likely drew on earlier records. Here it is explained that an image of Myōken was found in a river after a young daughter of a Watarai priest had drowned there in 859. After her

14 Felicia Bock's translation of the passage (Engi-Shiki: Procedures of the Engi Era, Tokyo: Sophia University, 1970, vol. 1 p. 167), which states that lanterns 'are lighted,' is mistaken.

15 Murayama Shūichi 村山修一, Nihon onmyōdō-shi sōsetsu
日本陰陽道史総説, Hanawa Shobō, 1991, p. 37.

Culture and Cosmos 
father had the image installed, he was blessed with three pairs of male twins in the course of three years. The legend suggests that the daughter had been a manifestation of Myōken, the Pole Star, who sacrificed herself to give the Watarai lineage sons. The same text states that another Watarai priest received an oracle from 'Myōken Sonjōō 妙見尊星王' (the Pole Star) in 888, urging him to worship the stars, the sun and the moon. This was the (legendary) origin of the so-called Yamamiya-sai 山宮祭 or Mountain Shrine festival, which was celebrated at Okazaki by Watarai clan members until the late Edo period. At this festival, the first Watarai priest led his kinsmen in a ritual of offering to Myōken, the sun and the moon, the protective deities for the twelve months of the year and the twenty-eight lunar mansions - although it is difficult to know when exactly these became the main divinities (honzon 本尊) of this ritual.

Okada Seishi also refers to the Yamamiya-sai in his history of the Ise shrines. He mentions the fact that the oldest ritual site where this ritual was performed was located at the eastern end of the summit of Takakurayama, and interprets this as another sign that Takakurayama, with its grave-mound on the top, was an ancient cult site of the Watarai clan. However, he does not mention that the rituals that were carried out at the site were in worship of the Pole Star - although we do not know from what date.

There is even an early medieval ritual manual that identifies the deities of Ise quite explicitly with the Pole Star and the seven stars of the Northern Dipper. The title of this manual is Tenshō Daijin giki 天照太神儀軌 ('Ritual manual of Amaterasu'), and it can be dated quite credibly to the late Heian period. I have published a detailed analysis of this manual elsewhere ${ }^{16}$ and I will not discuss it in any detail here, other than to mention that, in this text, the shrines of Ise are described as sanctuaries of the Heavenly Realm (tendo 天道). The divine figures in this realm judge all sentient beings after their death and dispense karmic retribution for the good and evil acts that they have committed during their lives. The manual reflects rituals to worship fate-ordaining stars that gained popularity in the Insei period (1086-1192), such as the hokuto ho

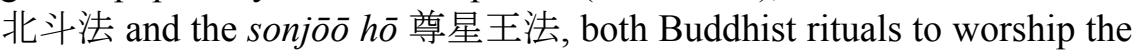
Pole Star and the Northern Dipper. As Hayami Tasuku has pointed out, 'the merging of beliefs in fate-ordaining stars and in Magistrates of the

16 Mark Teeuwen and Fabio Rambelli, eds, Buddhas and kami in Japan: Honji suijaku as a Combinatory Paradigm, London and New York: Routledge Curzon, 2003, chapter 5 . 
92 The imperial shrines of Ise: An ancient star cult?

Realm of the Dead is a characteristic of the Buddhism of aristocratic society during the Insei period. ${ }^{, 17}$ In my own analysis of this manual, I use it as an example of the nearly unlimited possibilities that the associative paradigm ${ }^{18}$ offered to shrines and temples that wished to adapt to new circumstances by reinventing themselves. What could be a more spectacular example of those possibilities than this ritual text, in which Ise, of all places, is transformed into the heavenly palace of the King of the Dead, appearing in the guise of the stars and planets in the sky?

Yet, a small doubt has remained at the back of my head. Was such a radical transformation possible without any pre-existing connection between Ise and the stars of heaven? Is it possible that such a connection did exist, even if there are no sources to attest it? Is it possible to quarry some indications for such a connection from Yoshino's imaginative but speculative work?

From the late twelfth century onwards, Outer Shrine priests wrote a large number of texts claiming that the deity of the Outer Shrine was identical to Ame no Minakanushi 天の御中主, the first deity of creation in the Kojiki. Ame no Minakanushi ('The Lord of the Centre of the Sky') is generally interpreted as an early Japanese equivalent to the Pole Star. If I may be allowed to be even more speculative than Yoshino - could it be argued that this identification of the Outer Shrine was not conjured up out of thin air, but actually did have some ancient precedent, remote though it may be?

\section{Conclusion}

I must let the questions asked in this paper stand unanswered. Even though I remain unconvinced by most of the details in Yoshino's work, I value it highly for its boldness in asking questions that are generally regarded as improper and beside the point. Unfortunately, lack of evidence prevents us from making any further progress; but at least,

17 Hayami Tasuku 速水侑, Heian kizoku shakai to bukkyō 平安貴族社会と仏教, Tokyo: Yoshikawa Kōbunkan 1975, pp. 252-4.

18 This paradigm, known as honji suijaku, identifies Japanese deities as local 'traces' (suijaku 垂迹) or manifestations of 'original' (honji 本地) buddhas. It inspired the creation of networks of criss-crossing identifications of Japanese, Chinese and Indian deities, demons, bodhisattvas, buddhas, and even people, and informed a wave of new rituals, doctrines and texts. See Teeuwen and Rambelli, eds, op.cit., chapter 1.

Culture and Cosmos 
Yoshino forces us to reconsider the nature of Ise as a purely Japanese sun cult, and helps us to recognise the possibility of Chinese imagery and symbolism, including that of the imperial Pole Star cult.

Let me conclude my paper by pointing out that my narrower concern with the ancient imagery of the Ise shrines also feeds into a larger question concerning the relationship between the kami cult of the classical court and Chinese cosmology. Throughout the classical period, incidents at Ise and other shrines were routinely put to the On'yōryō 陰陽寮 or 'Bureau of Yin and Yang,' where scholars schooled in Yijing divination decided what these incidents could mean, and what kinds of measures should be taken to avert possible dangers. Similarly, accidents at court, for example when the emperor fell ill, were also put to the On'yōryō, and it was expected of this bureau to find out from which geographical direction the evil influences originated, which shrines or temples were responsible, and what kind of ritual measures should be taken to counteract them. The will of the kami, then, was read and interpreted not by kami priests, but by specialists of Chinese cosmology. Surely, this fact should have large consequences for our understanding of the kami cult and its place in court society. Ever since Tsuji Zennosuke presented his theory of the interaction between Buddhism and kami cults in 1907, this has been a classical topic within the study of the history of Japanese religion. However, the question of how both Buddhist and kami rituals related to Chinese cosmology, for example in the non-Buddhist rituals of the Chinese imperial court, is only beginning to be addressed now. I am convinced that studies in this field will transform our understanding not only of early Japanese court ritual, but of Japanese religious history as a whole. 
94 The imperial shrines of Ise: An ancient star cult?

Fig 1. Detail of the cover offered to the Inner Shrine. From Jingū Chōkokan 神宮徵古館, ed., Jingū goshinpo zuroku 神宮御神宝図録, Ise 1995.

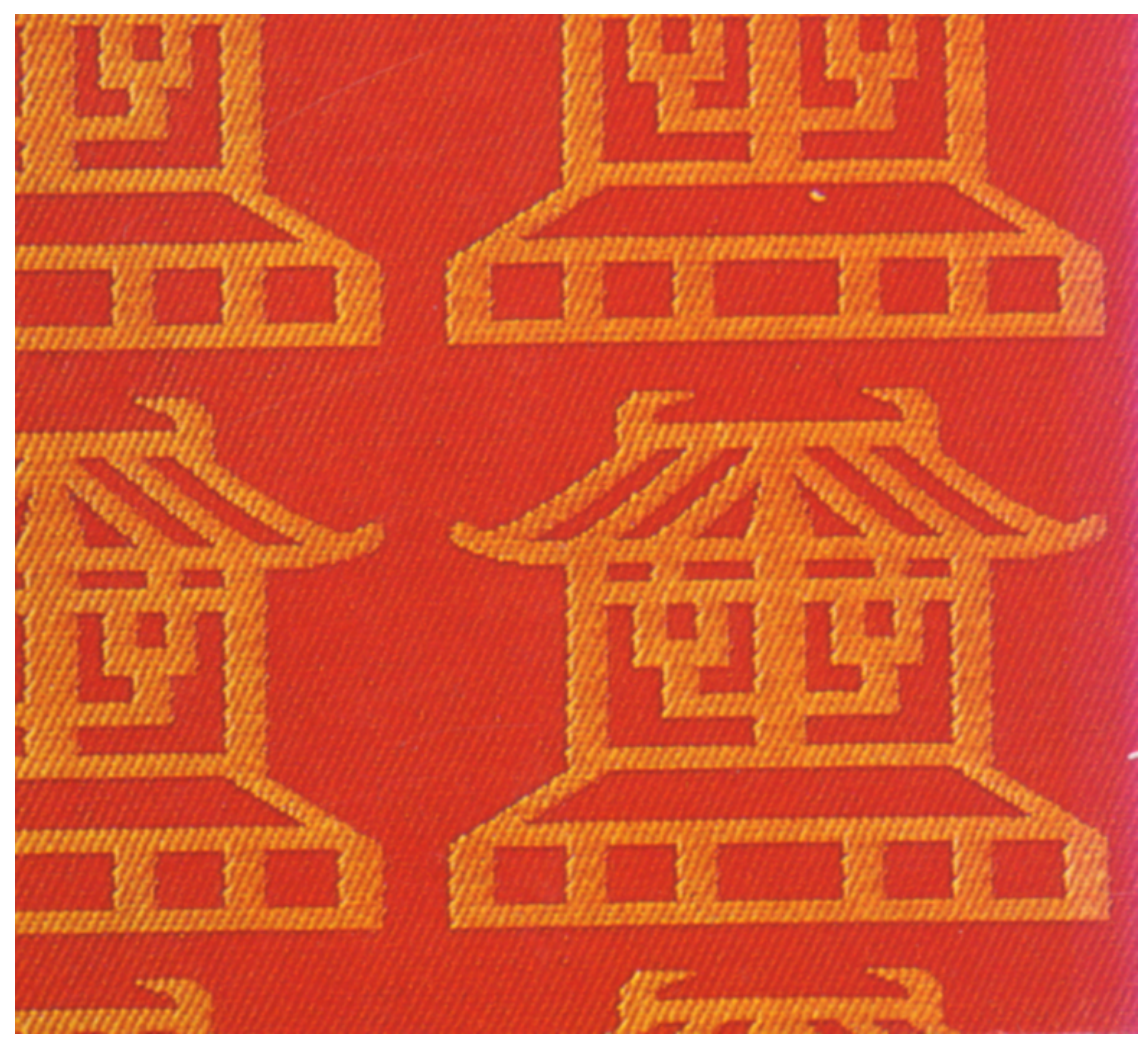

Culture and Cosmos 
Fig. 2a Cover offered to the Outer Shrine. From Jingū Chōkokan 神宮徵古館, ed., Jing ū goshinpō zuroku 神宮御神宝図録, Ise 1995.

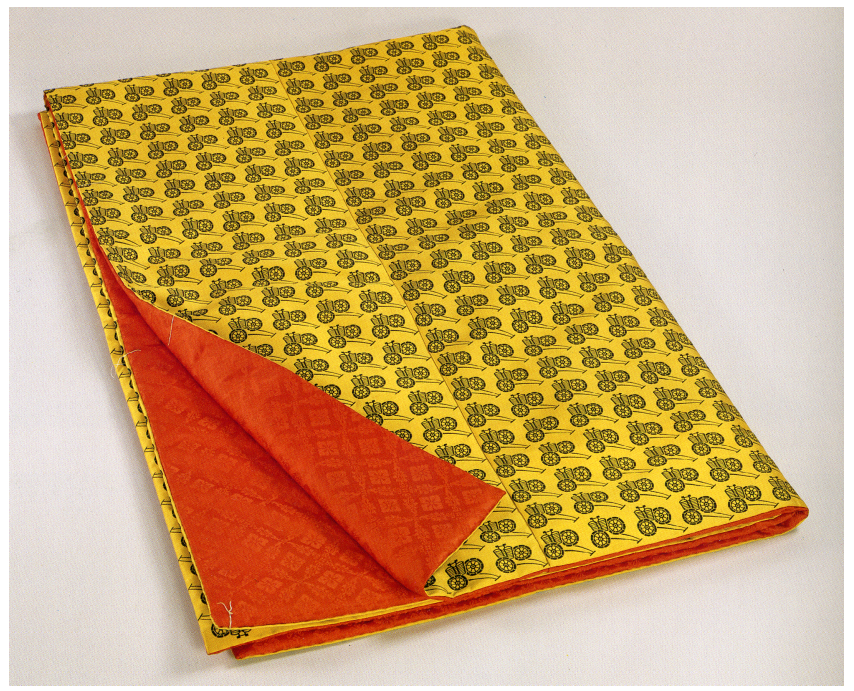

Fig. 2b Detail.

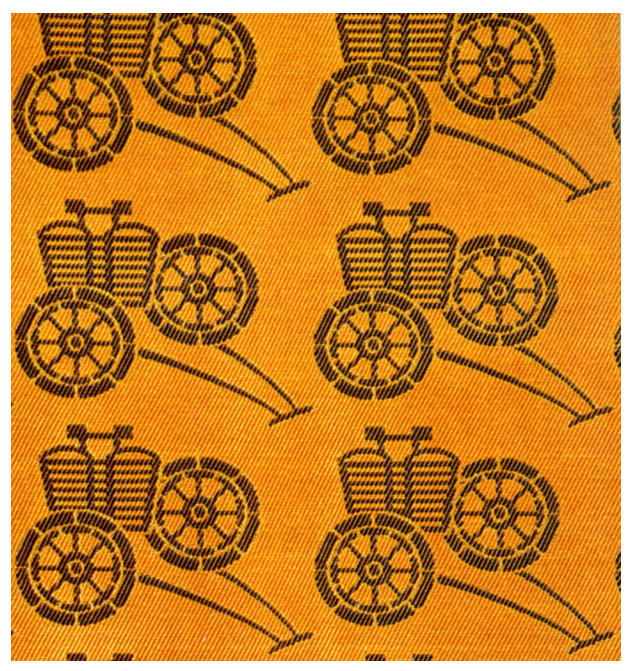


96 The imperial shrines of Ise: An ancient star cult?

Fig. 3 The angle between the Northern and Southern Dipper, measured from the Pole Star, in the hours when the ritual of the daijōsai would start (19 December, 10:00 pm). From Yoshino Hiroko, Tennō no matsuri, Kodansha 2000, p. 162.

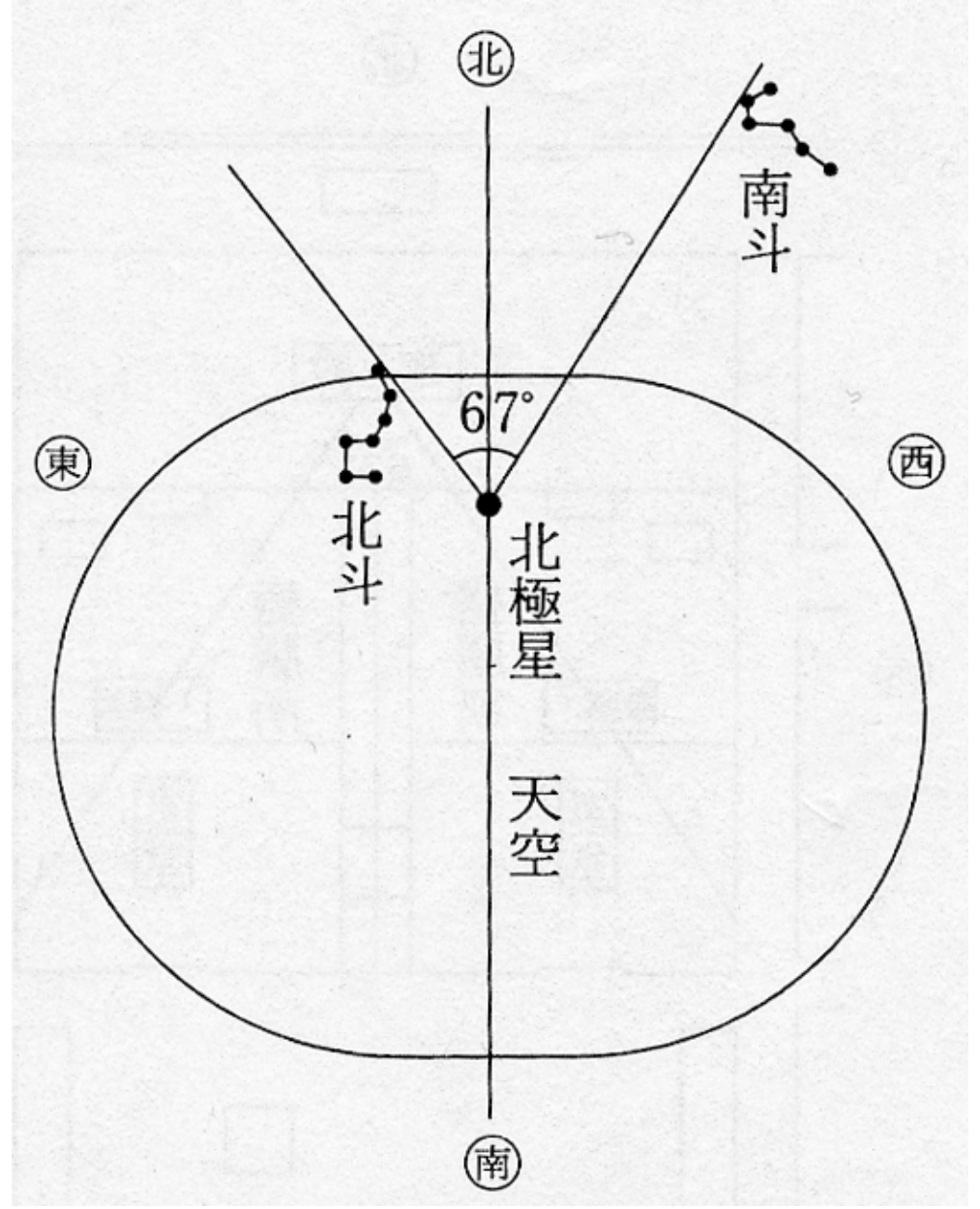

Culture and Cosmos 
Fig. 4 Layout of the Inner Ise Shrine. From Yoshino Hiroko, Tennō no matsuri, Kodansha 2000, p. 138.

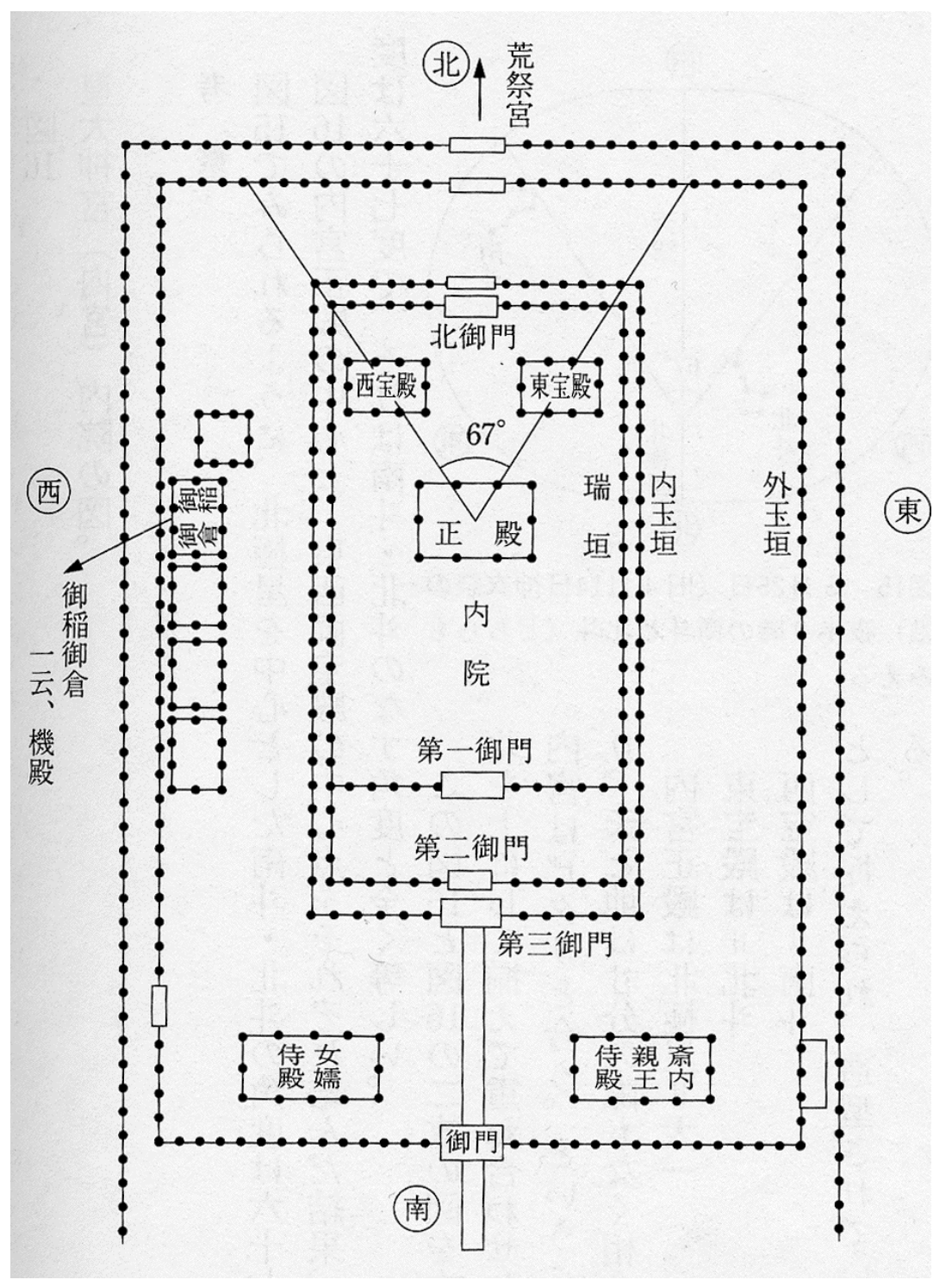


98 The imperial shrines of Ise: An ancient star cult?

Fig. 5 Layout of the Daijōgū. From Yoshino Hiroko, Tennō no matsuri, Kodansha 2000, p. 161.

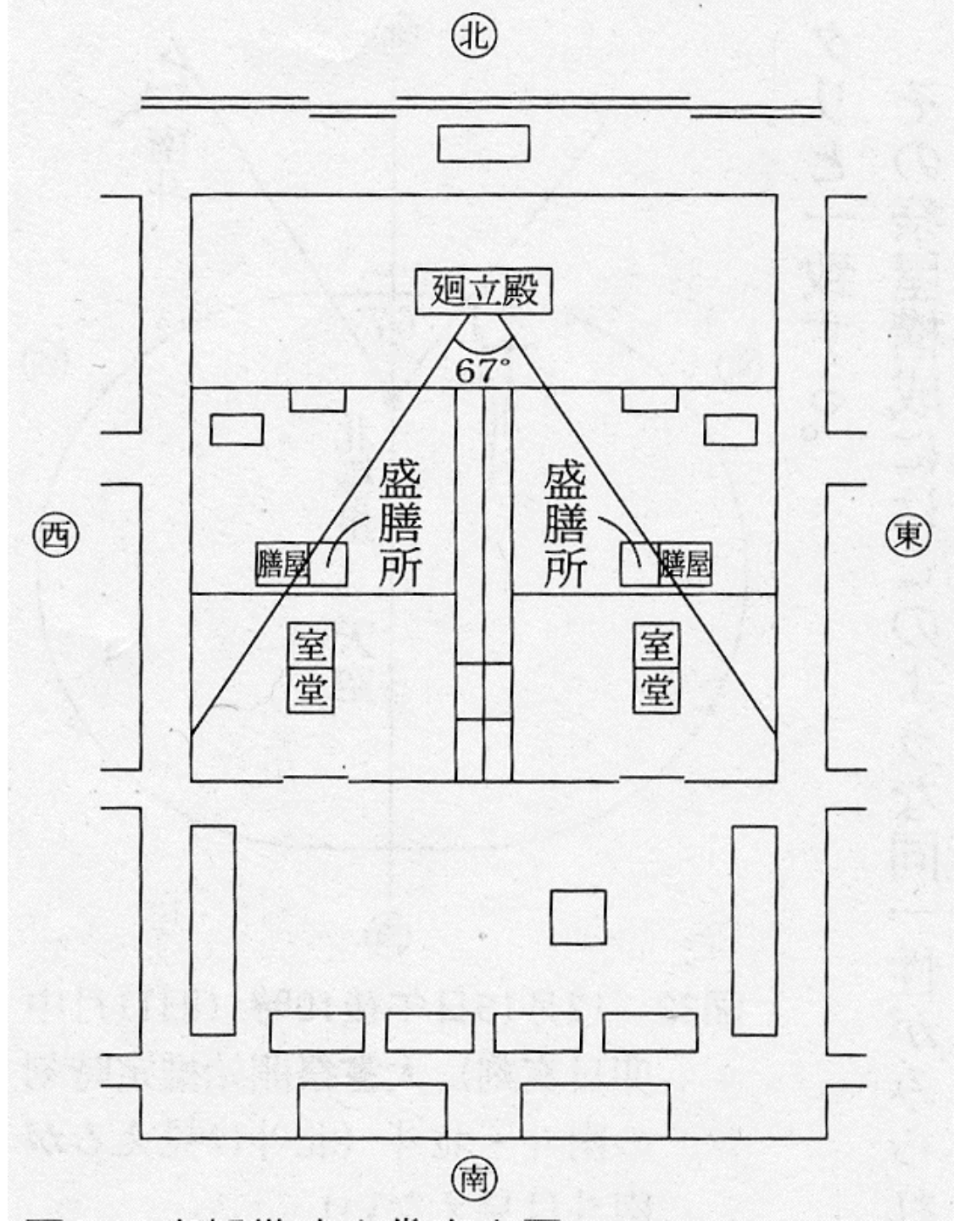

Culture and Cosmos 